\title{
Waveguide Iris Polarizers for Ku-band Satellite Antenna Feeds
}

\author{
S.I. Piltyay*, A.V. Bulashenko ${ }^{\dagger}$, I.V. Demchenko \\ National Technical University of Ukraine "Igor Sikorsky Kyiv Polytechnic Institute", \\ 37, Peremohy Ave., 03056 Kyiv, Ukraine
}

(Received 24 July 2020; revised manuscript received 15 October 2020; published online 25 October 2020)

\begin{abstract}
At the present day, antennas and signals with dual or single circular polarizations are widely used in modern satellite telecommunication systems, television systems, satellite navigation systems, civil and military radars, mobile communication systems, wireless identification systems and wireless data networks. The widespread application of signals with circular polarizations is caused by their advantages over signals with polarization of other types. The key element of antenna systems with circular polarizations is a polarizer. It is a microwave device, which performs the transformation of the circularly polarized electromagnetic waves into the linearly polarized waves or vice versa. The combination of a polarizer and an orthomode transducer in the antenna feeds carries out the full conversion of two signals with orthogonal circular polarizations and their transmission to the isolated waveguide ports. This article presents results of the development, optimization and analysis of new designs of compact polarizers based on a square waveguide with irises. The characteristics of polarizers with different number of irises have been optimized for the operation in Ku-band 10.7-12.8 GHz. The electromagnetic characteristics of the waveguide polarizers were simulated and optimized using finite integration technique. The evolution of sizes of optimal polarizer designs and improvement of their performance have been analyzed for the polarizers with 3 and 4 irises. The better characteristics among the investigated waveguide iris polarizer designs are provided by the polarizer with 4 irises. Developed compact square waveguide polarizer with 4 irises provides highlyefficient performance in the operating Ku-band $10.7-12.8 \mathrm{GHz}$ and can be widely used in modern antenna feeds for satellite information systems.
\end{abstract}

Keywords: Polarizer, Waveguide, Iris, Circular polarization, Differential phase shift, Axial ratio, Crosspolar discrimination, Satellite antennas, Antenna feed.

DOI: 10.21272/jnep.12(5).05024

PACS numbers: 84.40.Az, 84.40.Ua

\section{INTRODUCTION}

The type of electromagnetic wave polarization has an important influence on the features of its propagation process in the wireless link [1,2]. The application of signals with circular polarizations reduces the fading effect and destructive interference of the signals caused by the multipath propagation. The signals, which reflect from the Earth surface or from other objects, change their polarization to an orthogonal one for each reflection. Thus, the level of distorting signals with an odd number of reflections in the receiving antenna would be negligibly small.

Another advantage of the application of signals with circular polarizations is the absence of need for the accurate angular orientation between the transmitting and receiving antennas to establish the communication process [1-5]. The mentioned peculiarity distinguishes circular polarization from the linear polarization, for which high signal losses may occur due to the orientation mismatch of polarization planes of the transmitting and receiving antennas.

The application of signals with circular polarization increases the efficiency of radar systems [4]. It is quite difficult to create absorbent materials that would not reflect electromagnetic waves with circular polarization. Furthermore, the radars with circular polarization are more effective for radiolocation under rainy conditions, because interference noises, which are created by reflection of electromagnetic waves with circular polarization from water drops, are lower than in the case of reflection of waves with linear polarization [4].

All mentioned advantages explain why antennas and signals with circular polarizations are widely applied in modern wireless, radar and satellite systems for various purposes. Therefore, the development and optimization of characteristics of new waveguide polarizers for satellite antenna feeds is an important engineering problem, which is solved in this article.

\section{MODERN WAVEGUIDE POLARIZERS AND THEIR POLARIZATION CHARACTERISTICS}

Polarizer is a microwave device, which performs the transformation of electromagnetic waves with linear polarization into circularly polarized ones or vice versa. Consequently, the polarizer of the antenna system determines its differential phase shift, axial ratio and crosspolar discrimination (XPD).

One of the most frequently used types of waveguide polarizers is a septum polarizer [6-8]. The main advantage of the septum polarizer is its compact design, which integrates an orthomode transducer and a polarizer itself in a single structure. The disadvantage of a septum polarizer, which limits its application in some modern satellite communication systems, is the narrow operating frequency bandwidth. In [7], it has been demonstrated that the fractional bandwidth of a sep-

\footnotetext{
*crosspolar@ukr.net

$\dagger$ an_bulashenko@i.ua

†icegloom@gmail.com
} 
tum polarizer can reach only $20 \%$, if the isolation higher than $25 \mathrm{~dB}$ and XPD higher than $30 \mathrm{~dB}$ are simultaneously required in the antenna feed system.

The iris polarizer [9-13] is an alternative design of the waveguide polarizer, which provides better performance and wider fractional bandwidth. On the one hand, in dual-polarization antenna systems a waveguide iris polarizer functions only in the combination with an orthomode transducer [9], which makes the feed structure more complicated. On the other hand, much better performance can be obtained in the same operation frequency band using a waveguide iris polarizer compared to a septum polarizer. Better symmetry of the structure and lower polarization distortions can be obtained in the waveguides with axial symmetry $\mathrm{C}_{4}$ or $\mathrm{C}_{\infty}$. Typical examples of waveguides with such symmetry are quad-ridged waveguides $[14,15]$, on which coaxial and other orthomode transducers and polarizers are based [16-20]. The main disadvantage of such waveguides is difficulty of manufacture. Thus, the design based on a square waveguide with irises was chosen to develop polarizers for satellite antenna feeds.

Electromagnetic characteristics of a polarizer are the operation frequency band, peak level of VSWR for both polarizations, differential phase shift, axial ratio, isolation and/or XPD. In antenna feeds with two orthogonal polarizations a waveguide iris polarizer is applied in a combination with an orthomode transducer, which defines isolation of the whole antenna feed system [9]. All other polarization parameters of the feed system are determined exactly by the applied waveguide polarizer.

Typically, a waveguide polarizer provides good matching for electromagnetic waves of both polarizations. The amplitudes of field components with orthogonal linear polarizations at the polarizer input and output are equal with high accuracy. In this case, the equality of amplitudes of the components for both polarizations at the input leads to their equality at the output of a polarizer. In fact, the matching is imperfect. Thus, to calculate the polarization characteristics of a polarizer one must take into account not only differential phase shift, but also the difference between amplitudes of electric field components with orthogonal linear polarizations at the output of a polarizer.

Using a logarithmic scale, the formula for calculating the axial ratio can be expressed in $\mathrm{dB}$ as follows [6]:

$$
r(\mathrm{~dB})=10 \lg \frac{A^{2}+B^{2}+\sqrt{A^{4}+B^{4}+2 A^{2} B^{2} \cos (2 \Delta \phi)}}{A^{2}+B^{2}-\sqrt{A^{4}+B^{4}+2 A^{2} B^{2} \cos (2 \Delta \phi)}}
$$

where $A, B$ denote the amplitudes of orthogonal linearly polarized field components, $\Delta \varphi$ is the differential phase shift between them at the output of the polarizer.

Equivalent characteristic of the polarization is XPD. It is expressed in $\mathrm{dB}$ and can be calculated as follows:

$$
\mathrm{XPD}(\mathrm{dB})=20 \lg \left(\frac{r+1}{r-1}\right)
$$

where $r$ is the axial ratio (1), which preliminary must be converted into a linear scale.

\section{RESULTS OF OPTIMIZATION OF WAVEGUIDE IRIS POLARIZER CHARACTERISTICS}

Finite integration technique was used to simulate and optimize characteristics of square waveguide polarizers with 3 and 4 irises. The results of numerical simulations are presented in this section.

\subsection{Characteristics of a Polarizer with Three Irises}

Fig. 1 demonstrates the inner structure of a square waveguide polarizer with 3 irises. Designations of all sizes of the structure are also given in Fig. 1. Two outer irises have the same heights $h_{1}$. They are lower than the central iris with the height $h_{2}$ for matching improvement. The thicknesses of all irises are equal to $w$ and the gaps between them are equal to $L_{1}$.

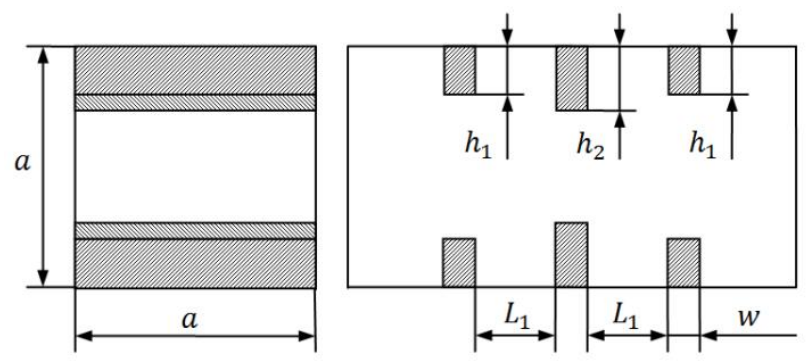

Fig. 1 - Inner structure of a waveguide polarizer with 3 irises

Fig. 2 shows the dependences of VSWR of the optimized polarizer with 3 irises on frequency for both polarizations in the operating band $10.7-12.8 \mathrm{GHz}$. In Fig. 2, it is seen that the maximum value of VSWR for both polarizations is 2.03 and it is reached at the lowest frequency of the operating $\mathrm{Ku}$-band of $10.7 \mathrm{GHz}$.

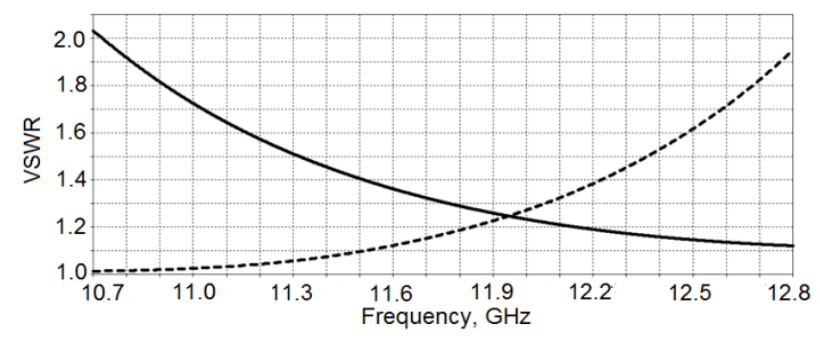

Fig. 2 - VSWR vs. frequency for the optimized polarizer with 3 irises: — horizontal polarization; ----- vertical polarization

Fig. 3 demonstrates the dependence of the differential phase shift of the optimized square waveguide polarizer with 3 irises on frequency in Ku-band. As one can see in Fig. 3, the differential phase shift is equal to $90^{\circ}$ at frequencies of $10.76 \mathrm{GHz}$ and $12.63 \mathrm{GHz}$. In the operating Ku-band $10.7-12.8 \mathrm{GHz}$, the differential phase shift of a square waveguide polarizer with 3 irises alters from $86^{\circ}$ to $91.6^{\circ}$. The maximum deviation of the differential phase shift from $90^{\circ}$ is $4^{\circ}$ and it occurs at a frequency of $11.7 \mathrm{GHz}$, which is close to the central frequency of the operating Ku-band.

Therefore, the application of 3 irises in the structure is enough to obtain the differential phase shift, which is quite close to $90^{\circ}$ in $18 \%$ fractional band- 
width. In this case, the main problem is bad matching of the waveguide polarizer with 3 irises due to a small number of discontinuities in the structure. Consequently, to improve matching of the square waveguide polarizer the number of irises must be increased.

The frequency dependences of the axial ratio and XPD of the optimized polarizer based on a square waveguide with 3 irises in the operating Ku-band are shown in Fig. 4 and Fig. 5, respectively.

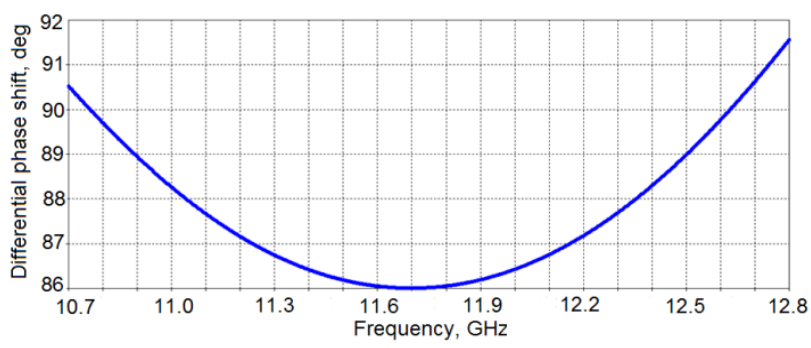

Fig. 3 - Differential phase shift of a polarizer with 3 irises

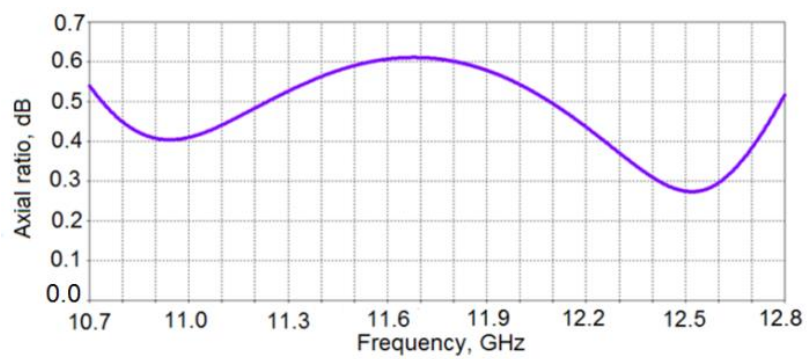

Fig. 4 - Axial ratio vs. frequency for a polarizer with 3 irises

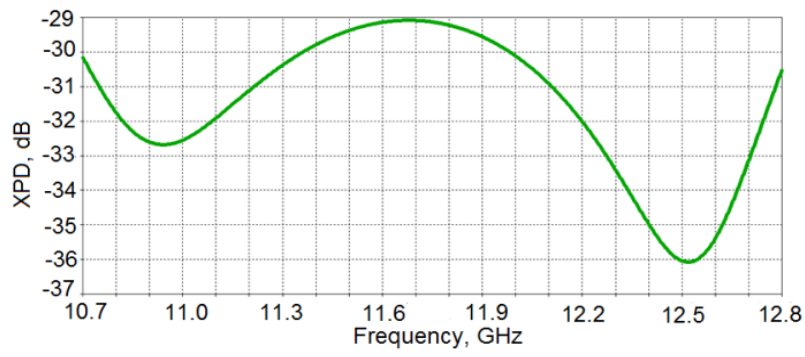

Fig. 5 - XPD vs. frequency for a polarizer with 3 irises

In Fig. 4, it is seen that in the operating frequency band $10.7-12.8 \mathrm{GHz}$ the axial ratio of the optimized square waveguide polarizer with 3 irises is less than $0.61 \mathrm{~dB}$. As one can observe in Fig. 5, the corresponding $\mathrm{XPD}$ of the polarizer is higher than $29 \mathrm{~dB}$. The maximum axial ratio (as well as the lowest XPD) is observed at a frequency of $11.7 \mathrm{GHz}$, which with high accuracy corresponds to the frequency of the maximum deviation of differential phase shift of the polarizer from $90^{\circ}$.

Consequently, in the operating frequency band 10.7$12.8 \mathrm{GHz}$ the optimized square waveguide polarizer with 3 irises provides VSWR for both polarizations less than 2.03. Its differential phase shift lies within the range of angles $90^{\circ} \pm 4^{\circ}$. The axial ratio is less than $0.61 \mathrm{~dB}$ and the XPD is higher than $29 \mathrm{~dB}$.

\subsection{Characteristics of a Polarizer with Four Irises}

The inner design of a square waveguide polarizer with 4 irises and designations of all its sizes are shown in Fig. 6. Two outer irises have the same heights $h_{1}$. To improve the matching of the structure the outer irises are lower than two inner irises with the heights $h_{2}$. The thicknesses of all irises are equal and designated as $w$.
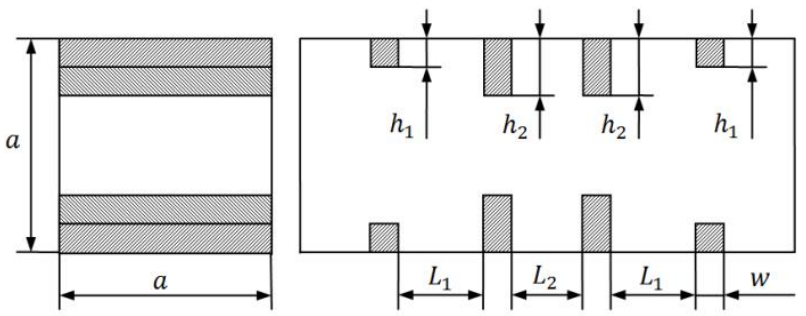

Fig. 6 - Inner design of a waveguide polarizer with 4 irises

Fig. 7 presents the dependences of VSWR for the optimized square waveguide polarizer with 4 irises on frequency for two fundamental modes of both linear polarizations in the operating $\mathrm{Ku}$-band 10.7-12.8 GHz. As one can see in Fig. 7, the maximum level of VSWR for both linear polarizations is 1.24 and it is reached at several frequencies within the Ku-band.

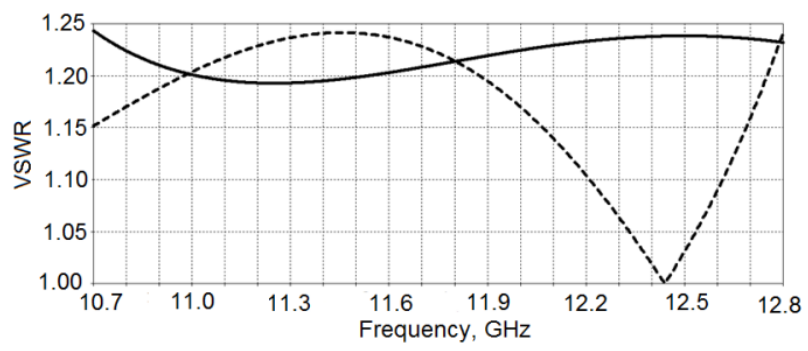

Fig. 7 - VSWR vs. frequency for the optimized polarizer with 4 irises: — horizontal polarization; --.-- vertical polarization

It is seen in Fig. 7 that the dependences of VSWR on frequency for the optimized square waveguide polarizer with 4 irises are not monotonic functions in contrast to the ones for the polarizer with 3 irises, which is demonstrated in Fig. 2. It is caused by the fact that in the case of the structure with 4 or more irises there occur strong interactions between higher order modes, which are excited at the irises.

The dependence of the differential phase shift of the optimized square waveguide polarizer with 4 irises on frequency is shown in Fig. 8. As one can see in Fig. 8, the differential phase shift is equal to $90^{\circ}$ at the frequencies of 10.94 and $12.71 \mathrm{GHz}$. In the operating Kuband 10.7-12.8 GHz, the differential phase shift of the polarizer with 4 irises varies from $86.5^{\circ}$ to $92.1^{\circ}$. The maximum deviation of the differential phase shift from $90^{\circ}$ is $3.5^{\circ}$ and it is observed at a frequency of $11.9 \mathrm{GHz}$.

The dependences of the axial ratio and XPD of the optimized polarizer with 4 irises on frequency in the operating Ku-band are shown in Fig. 9 and Fig. 10, respectively. 


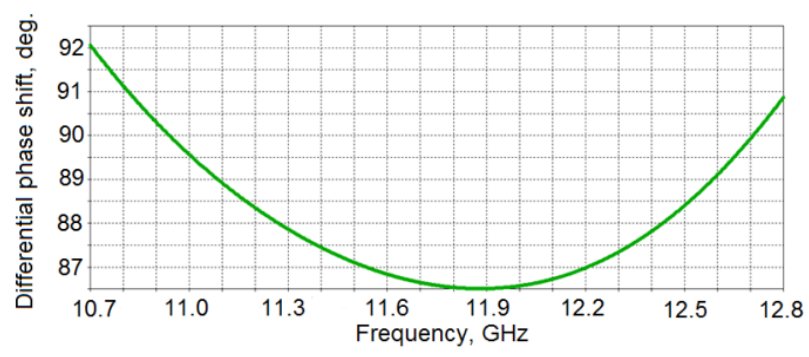

Fig. 8 - Differential phase shift of a polarizer with 4 irises

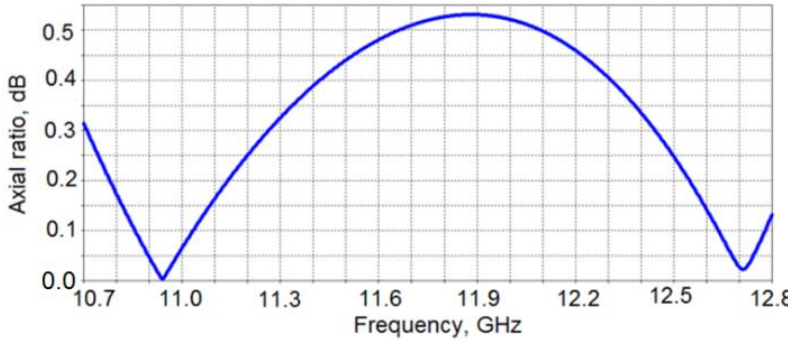

Fig. 9 - Axial ratio vs. frequency for a polarizer with 4 irises

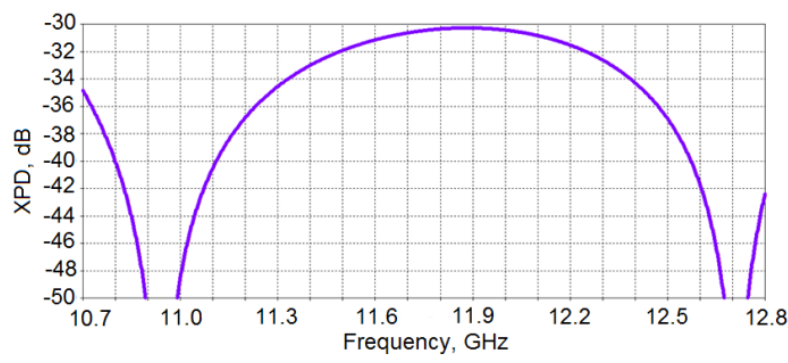

Fig. 10 - XPD vs. frequency for the polarizer with 4 irises

In Fig. 9, one can see that in the operating Ku-band $10.7-12.8 \mathrm{GHz}$ the axial ratio of the optimized square waveguide polarizer with 4 irises is less than $0.53 \mathrm{~dB}$. In Fig. 10, it is observed that the corresponding XPD of the polarizer is higher than $30.3 \mathrm{~dB}$. Two minima of the dependences of the axial ratio and XPD on frequency occur at frequencies of 10.94 and $12.71 \mathrm{GHz}$, which coincide with the frequencies corresponding to the differential phase shift of $90^{\circ}$.

Therefore, in the operating Ku-band $10.7-12.8 \mathrm{GHz}$ the optimized polarizer based on a square waveguide with 4 irises provides the following characteristics: VSWR for the fundamental modes of both linear polarizations is less than 1.24 , the differential phase shift lies within the range $90^{\circ} \pm 3.5^{\circ}$, the axial ratio is less than $0.53 \mathrm{~dB}$, the XPD is higher than $30.3 \mathrm{~dB}$.

\section{DISCUSSION OF OPTIMIZATION RESULTS}

Table 1 presents all inner sizes of square waveguide iris polarizer designs, which were optimized for the operating Ku-band 10.7-12.8 GHz. As one can see in Table 1, the increase in a number of irises leads to the decrease in the size $a$ of square waveguide walls, which makes the polarizer more compact in the transverse plane.

Table 2 presents the comparison of characteristics of the optimized square waveguide polarizers with 3 and 4 irises in the Ku-band 10.7-12.8 GHz.
Table 1 - Sizes of the optimized Ku-band iris polarizers

\begin{tabular}{|c|c|c|c|c|c|c|c|}
\hline 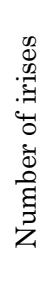 & 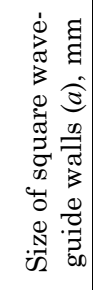 & 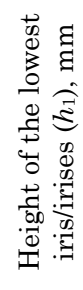 & 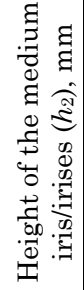 & 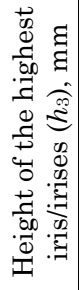 & 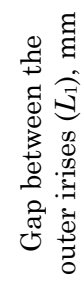 & 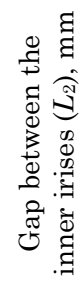 & 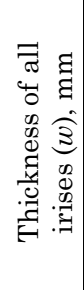 \\
\hline 3 & 21.98 & 2.45 & 3.86 & - & 4.92 & - & 2.79 \\
\hline 4 & 21.61 & 1.77 & 2.99 & - & 5.86 & 4.68 & 3.44 \\
\hline
\end{tabular}

When the larger number of irises is used in the polarizer design, then the differential phase shift introduced by each iris becomes lower, because the full differential phase shift at the polarizer output must be close to $90^{\circ}$ for each considered design. This leads to the decrease in heights of the irises as their number increases, which is seen in Table 1. Besides, the decrease in the iris heights improves matching of the polarizer structure that can be observed in Table 2 .

As one can see in Table 1, the thickness of irises of the waveguide polarizers operating in the $\mathrm{Ku}$-band $10.7-12.8 \mathrm{GHz}$ lies within the range $2.8-3.4 \mathrm{~mm}$, i.e. it weakly depends on the number of irises.

Table 2 - Characteristics of the optimized Ku-band polarizers

\begin{tabular}{|c|c|c|c|c|}
\hline $\begin{array}{c}\text { Number } \\
\text { of irises }\end{array}$ & $\begin{array}{c}\text { Maximal } \\
\text { VSWR }\end{array}$ & $\begin{array}{c}\text { Differential } \\
\text { phase shift }\end{array}$ & $\begin{array}{c}\text { Axial } \\
\text { ratio, } d B\end{array}$ & $\begin{array}{c}\text { XPD, } \\
\mathrm{dB}\end{array}$ \\
\hline 3 & 2.03 & $90^{\circ} \pm 4.0^{\circ}$ & 0.61 & 29.0 \\
\hline 4 & 1.24 & $90^{\circ} \pm 3.5^{\circ}$ & 0.53 & 30.3 \\
\hline
\end{tabular}

It is seen in Table 2 that the square waveguide polarizer with 3 irises does not provide matching required in most feed systems, because its maximum level of VSWR is higher than 1.3. Therefore, to provide simultaneously good matching and excellent polarization characteristics in the Ku-band 4 or more irises must be used in the design of a square waveguide polarizer.

\section{CONCLUSIONS}

Compact waveguide iris polarizers for $\mathrm{Ku}$-band satellite antenna feeds have been developed, optimized and analyzed in the article.

It has been found that the application of 3 irises in the structure of a waveguide polarizer is enough to provide the differential phase shift, which is quite close to $90^{\circ}$ in the $\mathrm{Ku}$-band. In this case, the main problem is bad matching due to a small number of discontinuities in the structure. The reflections from 3 irises do not compensate each other in the whole $18 \%$ fractional bandwidth.

The square waveguide polarizer with 4 irises provides VSWR less than 1.24. Its differential phase shift is $90^{\circ} \pm 3.5^{\circ}$. The axial ratio is less than $0.53 \mathrm{~dB}$, the $\mathrm{XPD}$ is higher than $30.3 \mathrm{~dB}$. Consequently, the square waveguide polarizer with 4 irises provides excellent polarization characteristics and meets the matching requirements of modern satellite antenna feeds. 


\section{REFERENCES}

1. W.L. Stutzman, G.A. Thiele, Antenna Theory and Design (New Jersey: John Wiley and Sons: 2013).

2. S. Gao, Q. Luo, F. Zhu, Circularly polarized Antennas Theory and Design (Chichester: John Wiley and Sons: 2014).

3. Y. Huang, K. Boyle, Antennas: From Theory to Practice (Chichester: John Wiley and Sons: 2008).

4. K. Chang, Encyclopedia of RF and Microwave Engineering (New Jersey: John Wiley and Sons: 2005).

5. N. Kinayman, M.I. Aksum, Modern Microwave Circuits (Norwood: Artech House: 2005).

6. J.A. Ruiz-Cruz, M.M. Fahmi, S.A. Fouladi, R.R. Mansour, IEEE T. Microw. Theory. 59 No 12, 3365 (2011).

7. F.F. Dubrovka, S.I. Piltyay, R.R. Dubrovka, M.M. Lytvyn, S.M. Lytvyn, Radioelectron. Commun. Syst. 63 No 1, 15 (2020).

8. N. Nikolic, A. Weily, I. Kekic, S.L. Smith, K.W. Smart, IEEE International Symposium on Antennas and Propagation \& USNC/URSI National Radio Science Meeting (APUSNCURSINRSM), art. No 8608909, 725 (Boston: IEEE: 2018)

9. S.I. Piltyay, XI IEEE International Conference on Antenna Theory and Techniques (ICATT), art. No 7972644, 284 (Kyiv: IEEE: 2017).

10. F.F. Dubrovka, S.I. Piltyay, IX IEEE International Conference on Antenna Theory and Techniques (ICATT), art. No 6650816, 473 (Odesa: IEEE: 2013).
11. G. Virone, R. Tascone, O.A. Peverini, G. Addamo, R. Orta, IEEE Microw. Wirel. Co. 18 No 8, 509 (2008).

12. M.-H. Chung, D.-H. Je, S.-T. Han, European Microwave Conference (EuMC), art. No 6986643, 1146 (Rome: IEEE: 2014).

13. S.-M. Hwang, J.-M. Kim, K.-H. Lee, IEEE Asia-Pacific Conference on Antennas and Propagation (APCAP), art. No 6333202, 153 (Singapore: IEEE: 2012).

14. C. Granet, H.Z. Zhang, A.R. Forsyth, G.R. Graves, P. Doherty, G. Moorey, IEEE Antenn. Propag. M. 47 No 3, 13 (2005).

15. H.Z. Zhang, IEEE International Antennas and Propagation Symposium Digest, art. No 1551894, 647 (Washington: IEEE: 2005).

16. F.F. Dubrovka, S.I. Piltyay, VIII IEEE International Conference on Antenna Theory and Techniques (ICATT), art. No 6170737, 176 (Kyiv: IEEE: 2011).

17. A. Tribak, A. Mediavilla, J.L. Cano, M. Boussouis, K. Cepero, European Microwave Conference (EuMC), art. No 5295927, 73 (Rome: IEEE: 2009).

18. A. Mediavilla, J.L. Cano, K. Cepero, European Microwave Conference (EuMC), art. No 6459338, 1099 (Amsterdam: IEEE: 2012),

19. A.W. Pollak, M.E. Jones, IEEE Antenn. Wirel. Pr. 17 No 3 , 422 (2018).

20. J. Flygare, M. Pantaleev, IEEE T. Antenn. Propag. 68 No 1 , 207 (2020).

\title{
Хвилеводні поляризатори з діафрагмами для опромінювачів супутникових антен Ки-діапазону
}

\section{С.І. Пільтяй, А.В. Булашенко, І.В. Демченко}

\author{
Національний технічний університет Украӥни "Київський політехнічний інститут \\ імені Ігоря Сікорського", пр. Перемоги, 37, 03056 Київ, Украӥна
}

\begin{abstract}
У наш час антени та сигнали з двома або однією коловою поляризацією широко використовуються в сучасних супутникових телекомунікаційних системах, телевізійних системах, супутникових навігаційних системах, цивільних і військових радіолокаторах, системах мобільного зв'язку, радіотехнічних системах ідентифікації та бездротових мережах передачі даних. Широке застосування сигналів із коловою поляризацією обумовлено їх перевагами над сигналами з іншими видами поляризації. Ключовим елементом антенних систем з коловою поляризацією є поляризатор. Це надвисокочастотний пристрій, який виконуе перетворення електромагнітних хвиль із коловою поляризацією у хвилі з лінійною поляризацією або навпаки. Сумісне використання поляризатора та ортомодового перетворювача в опромінювачах антен забезпечуе повне перетворення двох сигналів з ортогональними коловими поляризаціями та їх передачу до розв'язаних хвилеводних портів. У цій статті представлено результати розробки, оптимізації та аналізу нових конструкцій компактних поляризаторів на основі квадратного хвилеводу з діафрагмами. Було виконано оптимізацію характеристик поляризаторів з різною кількістю діафрагм у Ku-діапазоні частот 10,7-12,8 ГГц. Моделювання й оптимізацію електромагнітних характеристик хвилеводних поляризаторів було здійснено за допомогою методу скінченного інтегрування. Було проаналізовано зміну розмірів оптимальних конструкцій поляризаторів і покращення їх характеристик для поляризаторів з 3 і 4 діафрагмами. Кращі характеристики серед досліджених конструкцій хвилеводних поляризаторів з діафрагмами має поляризатор з 4 діафрагмами. Розроблений компактний поляризатор на основі квадратного хвилеводу з 4 діафрагмами забезпечуе високоефективну роботу в Ки-діапазоні частот 10,7-12,8 ГГц і може широко використовуватися в сучасних антенах для супутникових інформаційних систем.
\end{abstract}

Ключові слова: Поляризатор, Діафрагма, Хвилевід, Диференційний фазовий зсув, Коефіціент еліптичності, Кросполяризаційна розв’язка, Супутникові антени, Опромінювач антени. 